\title{
Working
}

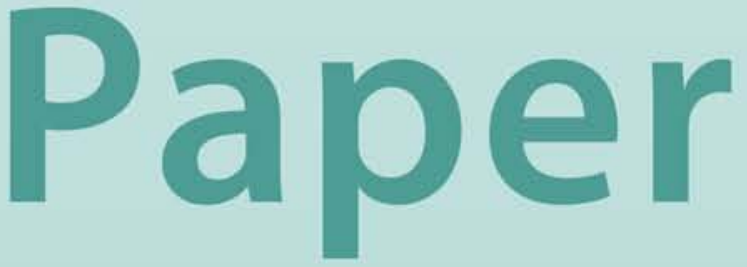




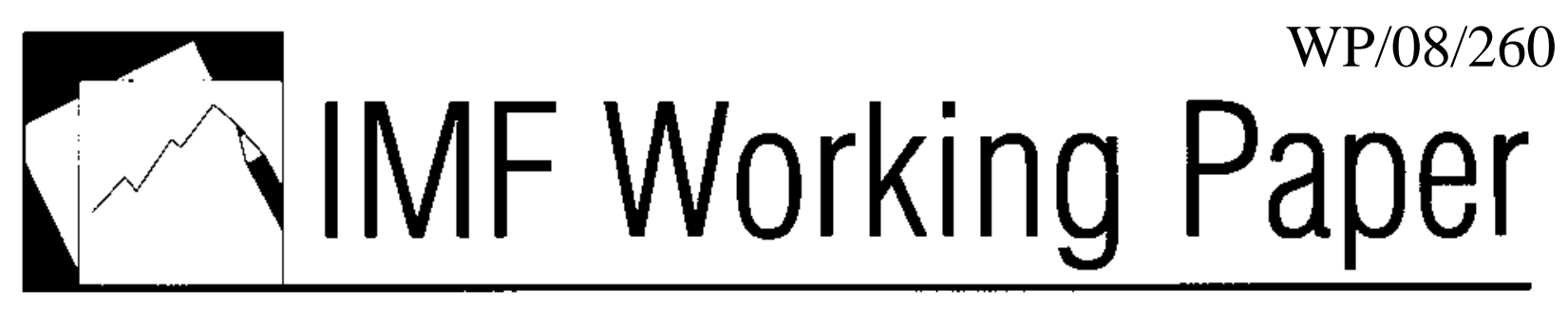

\section{Fundamentals at Odds? The U.S. Current Account Deficit and The Dollar}

Gian Maria Milesi-Ferretti 


\title{
IMF Working Paper
}

\author{
Research Department
}

\section{Fundamentals at Odds? The U.S. Current Account Deficit and The Dollar* \\ Prepared by Gian Maria Milesi-Ferretti}

November 2008

\begin{abstract}
This Working Paper should not be reported as representing the views of the IMF. The views expressed in this Working Paper are those of the author(s) and do not necessarily represent those of the IMF or IMF policy. Working Papers describe research in progress by the author(s) and are published to elicit comments and to further debate.

In mid-2008, the real effective exchange rate of the dollar was close to its minimum level for the past 4 decades. At the same time, however, the U.S. trade and current account deficits remain large and, absent a significant correction in coming years, would contribute to a further accumulation of U.S. external liabilities. The paper discusses the tension between these two aspects of the dollar assessment, and what factors can help reconcile them. It focuses in particular on the terms of trade, adjustment lags, and measurement issues related to both the real effective exchange rate and the current account balance.

JEL Classification Numbers:F31, F32

Keywords: Current account; U.S. dollar; real effective exchange rate

Author’s E-Mail Address:gmilesiferretti@imf.org

\footnotetext{
* Prepared for the June 27-28 Siena conference on "The Impact of Global Financial Imbalances" and forthcoming in Economic Notes. I am grateful to Abdul Abiad, Philip Lane, Jaewoo Lee, Jaime Marquez, Koshy Mathay, and conference participants for their comments, to Charlie Thomas and Jaime Marquez for sharing their WARP data, and to Luis Catão for data and calculations on daily dollar fluctuations. This paper is dedicated to the memory of my dear friend Leonardo Bartolini, wonderful human being and brilliant economist.
} 
I. Introduction

II. The Current Account Balance and The International Investment Position.

III. Some stylized Facts on the dollar and the U.S. current account.....................................

A. Two Dollar Cycle Episodes ........................................................................

B. A Comparison Between 2 Adjustment Episodes .............................................

IV. Reconciling Prices and Quantities ....................................................................... $\frac{8}{9}$

A. Is the REER Mismeasured? The WARP Argument …..........................................

B. Is The U.S. Current Account Deficit Overstated?.............................................10

C. Adjustment Lags .................................................................................. $\frac{12}{12}$

D. The Terms of Trade and Oil Prices .............................................................. $\frac{13}{14}$

E. External Adjustment and Shift in Relative Prices ..................................................14

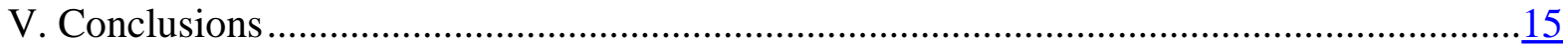

Tables

1. Historical Patterns of U.S. Dollar Real Depreciations (1973-2008) ..........................16

2. Historical Patterns of U.S. Dollar Nominal Depreciations (1976-2008) ....................17

3. The U.S. Current Account Balance and Oil Prices during the Adjuntment

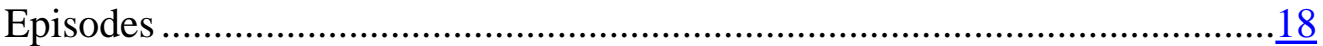

4. Cumulative Financial Flows and Changes in the U.S. International Investment Position.............................................................................19

Figures

1. Real Effective Exchange Rate, January 1973-September 2008 ...............................20

2. Current Account Balance and Non-Oil Balance on Goods and Services

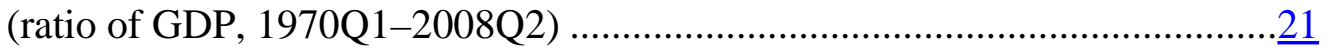

3. Real Effective Exchange Rate and "WARP" Index................................................22

4. Lagged "WARP" Index and Non-Oil Balance of Goods and Services ........................23

5. Non-Oil Trade Balance and Real Exchange Rate: Cross-Correlation

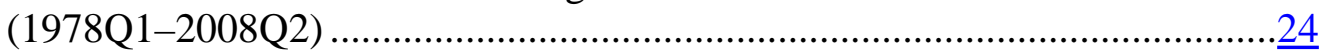

6. Terms of Trade and Oil Prices, 1973-2008 .....................................................

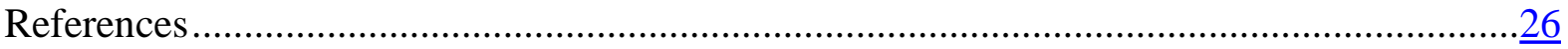




\section{INTRODUCTION}

After reaching a peak in February of 2002, the U.S. dollar depreciated by over 25 percent in real effective terms by mid-2008; vis-à-vis the world major currencies, the decline was even sharper (over 30 percent). Statements by Chairman Bernanke and Secretary Treasury Paulson (June 2008) highlighted concerns on the potential inflationary consequences of further dollar depreciation, and would suggest that the level of the dollar in mid-2008 was "too weak" in relation to the U.S. economy's underlying fundamentals.

At the same time, however, the U.S. current account deficit remains large. To be sure, the substantial weakening of the dollar in recent years has contributed to some reduction in that deficit, and with rapid growth in U.S. exports it is reasonable to project some further decline. Nevertheless, absent a very significant correction of the U.S. deficit, the accumulation of net external liabilities would gradually tend to worsen the U.S. income balance, adding to the pressure on external accounts arising from the still significant deficit in the balance of goods and services. In turn, this suggests that some further dollar adjustment may be necessary for the U.S. current account to return to a level that is 'sustainable' over the medium term.

This paper examines whether and how these conflicting implications on the path of the U.S. dollar can be reconciled. It starts by briefly documenting key stylized facts on the evolution of the dollar, the U.S. current account, and the U.S. external position over the past 3 decades. It then discusses several factors - measurement issues related to the real exchange rate and the U.S. current account balance, the role of oil prices and the terms of trade more generally, and the strength of the co-movement between trade and real exchange rates - that can help shed light on these stylized facts.

The literature on the large U.S. current account deficit during this decade and the so-called "global imbalances" — with its attendant implications for U.S. dollar adjustment-is voluminous, and a thorough review would warrant a paper by itself. A precursor to this literature is the paper by Obstfeld and Rogoff (2001) who first discussed the implications for the value of the dollar of the widening U.S. current account deficit. Their updated calculations, presented in Obstfeld and Rogoff $(2005,2007)$ highlight that a reduction of the U.S. current account balance to sustainable levels would need to be accompanied by a significant real effective depreciation of the dollar. Edwards (2005) and Krugman (2007) reach similar conclusions. Blanchard, Giavazzi, and Sa (2005) using a portfolio balance model also underscore the need for a substantial medium-term depreciation of the U.S. dollar, but envisage a protracted gradual "slide" rather than a large upfront adjustment. Laxton and Milesi-Ferretti (2005) and Faruqee et al. (2007) present scenarios of a reduction in global imbalances based on a multi-country dynamic-stochastic general equilibrium model which entail real effective depreciation of the dollar.

The notion that U.S. current account adjustment needs to be accompanied by changes in real effective exchange rates has not gone unchallenged. For example, Engel and Rogers (2006) argue that the widening of the U.S. current account balance may simply reflect an increase in the expected share of U.S. output relative to world output, and as such would not require a 
significant adjustment in relative prices. Similarly benign views on the need for U.S. dollar adjustment are expressed by Cooper (2008) and Dooley, Garber, and Folkerts-Landau (2005), while Fratzscher, Juvenal, and Sarno (2007) argue on the basis of VAR evidence that shocks to asset prices play a more important role in U.S. current account adjustment than exchange rate shocks. A parallel literature has focused on episodes of large current account adjustments in advanced economies to make inferences about what may be in store for the U.S. economy (Edwards, 2005; Croke, Kamin, and Leduc, 2006; Freund and Warnock, 2007). The literature suggests that episodes of current account adjustment in advanced economies are not necessarily associated with large exchange rate changes, while recognizing the difficulties of extrapolating the experience of small advanced economies to the United States.

At first blush, the evidence so far does not fully settle the debate. On the one hand, the notion that the U.S. current account deficit could continue indefinitely without a significant exchange rate adjustment has clearly been disproved by the data: as mentioned earlier, the dollar has depreciated significantly in real effective terms since its 2002 peak. On the other hand, despite the significant depreciation of the dollar the correction in the U.S. current account has so far been relatively modest. Hence the question that motivates the paper: why is a "weak" dollar associated with a large current account deficit? In the remainder of the paper, we discuss what factors can help shed light on this "fundamentals at odds" question.

\section{The Current Account BaLAnCE AND The InTERnational InVESTMEnt Position}

Before turning to the discussion of the evidence, it is useful to provide a simple accounting framework that relates the trade balance and the current account balance to the evolution of the net foreign asset position. This framework provides a useful reference point for an assessment of "current account sustainability"-a current account balance is "sustainable" to the extent that it does not give rise to an unbounded accumulation of net external liabilities.

The link between the current account balance $C A$ and the change in the net foreign asset position $B$ can be written as follows:

$$
\begin{aligned}
& B_{t}-B_{t-1}=C A_{t}+K G_{t}+E_{t} \\
& C A_{t}=T B_{t}+i_{t}^{A} A_{t-1}-i_{t}^{L} L_{t-1}
\end{aligned}
$$

where $K G_{t}$ is the capital gain or loss on net foreign assets (equal to the change in the net foreign asset position minus net capital outflows) and the term $E_{t}$ includes capital account transfers and errors and omissions that drive a wedge between a country's current account and net outflows of capital. In turn, the current account equals the sum of the balance on goods, services, and current transfers $T B$ and net investment income $i_{t}^{A} A_{t-1}-i_{t}^{L} L_{t-1}$, where $A$ and $L$ are external assets and liabilities, respectively, and $i_{t}^{A}, i_{t}^{L}$ are the nominal yields on these assets and liabilities. 
Let $\mathrm{kg}_{t}^{A}\left(\mathrm{~kg}_{t}^{L}\right)$ be the ratio of the capital gain on external assets (liabilities), measured in domestic currency, to the outstanding stock of external assets (liabilities) at the beginning of the period, so that $\mathrm{kg}_{t}^{A} A_{t-1}-k g_{t}^{L} L_{t-1}=K G_{t}$. Then the real rate of return on foreign assets, measured in domestic currency, will equal $r_{t}^{A}=\frac{1+i_{t}^{A}+k g_{t}^{A}}{1+\pi_{t}}-1$, where $\pi$ is the inflation rate. An analogous definition holds for the rate of return on foreign liabilities $r_{t}^{L}$. Using these definitions, we can re-write (1) as follows:

$$
b_{t}-b_{t-1} \equiv t b_{t}+\frac{r_{t}^{L}-g_{t}}{1+g_{t}} b_{t-1}+\frac{r_{t}^{A}-r_{t}^{L}}{1+g_{t}} a_{t-1}+\varepsilon_{t}
$$

where $g$ is the rate of GDP growth and the lower-case letters $(b, t b, a)$ indicate ratios to GDP of the respective $(B, T B, A)$ variables. Equation (2) shows that the evolution of a country's net external position depends on three main factors:

- the balance on goods, services, and transfers ("the trade balance"),

- net foreign assets relative to GDP, multiplied by the difference between the rate of return on external liabilities and the growth rate of the economy (broadly the growth rate of the numerator minus the growth rate of the denominator of the net foreign assets to GDP ratio),

- the difference in the rate of return between external assets and liabilities, weighted by the size of external assets relative to GDP.

The exchange rate can have an impact on the evolution of the external position through two main channels - the trade channel and the valuation channel. With regard to the first, an exchange rate appreciation will tend to worsen the trade balance (with a lag) and hence the external position. What matters for this channel is the exchange rate level-other things being equal, the more appreciated the currency the smaller the trade balance. With regard to the second, given that most U.S. foreign assets are denominated in foreign currency while U.S. foreign liabilities are predominantly denominated in dollars, an exchange rate appreciation in year $t$ will reduce the year $t$ 's rate of return earned on foreign assets, and thus worsen the net external position. What matters for this channel is the percentage change in the exchange rate- if the real exchange rate remains constant, the channel is not operative.

As of end-2007, the ratio of net external liabilities to GDP for the United States was about 20 percent of GDP (excluding gold holdings). The trade deficit (inclusive of services and transfers) currently projected for 2008 is around $4 \frac{1}{2}$ percent of GDP. The return on external liabilities over the past few years was close to the economy's growth rate, implying that the second term on the right-hand-side of equation (2) was negligible. Finally, the ratio of foreign assets to GDP was around 1.1. This would imply that, absent a very significant return differential between external assets and liabilities (4 percent or so) the U.S. external position 
would steadily deteriorate. This analysis of the intertemporal budget constraint provides a simple illustration of the argument that the U.S. trade and current account deficits need to fall over the medium term. Section IV.B returns to this issue in more detail.

\section{SOME STYLIZED FACTS ON THE DOLLAR AND THE U.S. CURRENT ACCOUNT}

Figure 1 depicts the evolution of the dollar's real effective exchange rate since the early 1970s. ${ }^{1}$ It identifies two long "cycles” in the dollar's real effective exchange rate-the appreciation between 1978 and 1985 and the subsequent depreciation between 1985 and 1991, and the appreciation between 1995 and 2002 and the subsequent depreciation between 2002 and 2008. Tables 1 and 2 provide some details on the main periods of dollar weakness, in both nominal and real effective terms, vis-à-vis all trading partners as well as vis-à-vis major currencies. ${ }^{2}$ It is interesting to note that the dollar has been significantly more volatile vis-à-vis major currencies than vis-à-vis all trading partners' currencies, reflecting the fact that several emerging market currencies move closely with the U.S. dollar.

Figure 2 depicts the evolution of the U.S. current account balance and the balance of goods and services net of oil (both in percent of GDP) since the early 1970s. While the current account balance displays a "full cycle" between 1980 and 1991, the current account adjustment in recent years has been (as of mid-2008) much more modest, despite a depreciated level of the dollar relative to its historical average. To shed light on this apparent inconsistency between the behavior of the dollar and the current account, we therefore start from a closer comparison of the two dollar-cycle episodes, focusing on the behavior of the current account balance and its underlying components.

\section{A. Two Dollar Cycle Episodes}

The episode of dollar appreciation and depreciation that took place during the 1980s has been extensively discussed in the literature (see, for example, Lawrence, 1990 and Krugman, 1991). Between January 1979 and March 1985 the dollar appreciated by almost 40 percent in real effective terms (Figure 1). ${ }^{3}$ During the same period, the current account balance went from near balance in 1978 to a deficit of 23/4 percent of GDP in 1985. The subsequent period of dollar depreciation had almost identical features, with the signs reversed-during the 6-

\footnotetext{
${ }^{1}$ This paper uses data available up to end-September 2008. In October 2008 the dollar posted its largest monthly real appreciation in the past 35 years-over 6 percent.

${ }^{2}$ Major currencies are the "euro legacy" currencies, the Australian dollar, the British pound, the Canadian dollar, the Japanese yen, the Swedish krona, and the Swiss franc. The analysis of the dollar's nominal effective exchange rate vis-à-vis all trading partners starts only in 1995 because previous years were characterized by very high inflation and depreciation in at least one of the U.S. trading partner countries. The end-points for the periods of nominal and real dollar adjustment (July 15, 2008 and March 2008, respectively) reflect the trough of the respective daily and monthly series (as of end-September 2008).

${ }^{3}$ Exchange rate changes are reported as log differences so as to allow a direct comparison between the extent of appreciation and depreciation. In percentage terms, the U.S. dollar appreciation was about 50 percent, according to the Federal Reserve Board broad dollar index.
} 
year period between March 1985 and February 1991 the U.S. dollar depreciated by about 40 percent in real effective terms and the current account balance reverted to broad equilibrium. The swings in the value of the U.S. dollar between the two periods were even sharper when measured against major currencies.

What were the consequences of this dollar "cycle” on the U.S. net external position? As of 1978, the U.S. was a net creditor, with net foreign assets totaling about 9 percent of GDP; by 1991 it was a net debtor, with net foreign liabilities of about 6 percent of GDP. ${ }^{4}$ In terms of the breakdown of changes in the external position illustrated by equation (2), the significant cumulative trade deficits more than fully explain the deterioration in the U.S. external position during this period.

The latest surge in the dollar occurred between mid-1995 and February 2002. During this period, the dollar appreciated by about 30 percent in real effective terms, and the current account deficit widened from 1/1/2 percent of GDP in 1995 to close to 41/2 percent of GDP in 2002. As during the early 1980s, the appreciation of the U.S. dollar was more pronounced vis-à-vis major currencies (40 percent) than vis-à-vis all trading partners. The subsequent period of dollar adjustment has once again brought the U.S. currency back to its initial trough level of mid-1995, with a 25 percent depreciation between February 2002 and March 2008. However, the turn-around in the U.S. current account balance has been much more modestfrom a peak of $6 \frac{1 / 2}{2}$ percent of GDP in the $4^{\text {th }}$ quarter of 2005 to just under 5 percent at the end of 2007—still higher than its level at the time of the U.S. dollar peak.

During this period, the U.S. net external position deteriorated from about -6 percent of GDP in 1995 to around -20 percent of GDP in 2007. As discussed in the next section, this deterioration was much more modest than the cumulative external borrowing by the United States during this period. Indeed, U.S. net foreign liabilities have remained virtually stable as a ratio of GDP between 2001 and 2007, despite record trade and current account deficits averaging 5 percent of GDP per year. ${ }^{5}$ As a result, the income balance has not deteriorated.

\section{B. A Comparison Between 2 Adjustment Episodes}

While determining the timing of dollar appreciation and depreciation episodes is straightforward, a relevant issue is the appropriate horizon over which adjustment episodes in the U.S. trade balance and current account should be compared. In light of the significant lags with which the trade balance responds to changes in the real effective exchange rate (discussed further in Section IV), we focus our comparison on the periods 1980-87

\footnotetext{
${ }^{4}$ At market value, the worsening of the net external position was smaller-from 5.5 percent of GDP to -3.2 percent of GDP.

${ }^{5}$ As discussed in Tille (2005), Curcuru, Dvorak, and Warnock (2008), Gourinchas and Rey (2007a, b), and Lane and Milesi-Ferretti (2007), valuation effects have played a big role since 2001: foreign equity prices have risen faster than U.S. equity prices, increasing the value of U.S. assets more than the value of U.S. liabilities, and the significant dollar depreciation has raised the dollar value of U.S. assets overseas denominated in foreign currencies. See the discussion in Section IV.
} 
(widening U.S. current account deficit) and 1987-91 (shrinking current account deficit) for the first episode and the periods 1997-2004 and 2004-08 for the second episode. These periods reflect—with a two-year lag — the long cycle in the real effective exchange rate.

Table 3 highlights developments in the current account balance, the dollar, and the U.S. cyclical position relative to trading partners during the two episodes. The two periods of widening U.S. current account deficits were associated with an appreciating U.S. dollar and a widening output gap in trading partners. While cyclical developments in the U.S. tended to widen the U.S. deficit in the 1980s relative to the more recent episode, the large drop in oil prices during the earlier period was reflected in an improvement in the U.S. oil trade balance of 1.8 percent of GDP, unlike in the latest episode.

Conversely, during the two "adjustment periods" the U.S. dollar was depreciating and the U.S. output gap widening relative to trading partners. However, the very modest correction of the U.S. current account balance after 2004 stands out. As it turns out, a number of factors help reconcile the features of the two adjustment episodes:

- The first is the behavior of oil prices: the worsening of the oil balance between 2004 and 2008 offset half of the 2 percentage points of GDP's improvement in the non-oil balance on goods and services.

- A second factor are the one-off transfers received by the U.S. in 1991 related to the financing of the Gulf war, that boosted the correction in the current account between 1987 and 1991.

- Almost half of the total dollar depreciation since 2002 has occurred during 2007-08, and its impact on the U.S. trade balance is arguably still in the pipeline. The strong growth in export volumes in late 2007 and early 2008 provides some supporting evidence in that respect.

- One final factor necessary to understand the significant difference between the current account deficit projected for 2008 and its balanced level in 1991 is the starting point of the latest episode (1995): in that year, the current account deficit had deteriorated back to 1.7 percent of GDP, even though the dollar was still close to its 1991 trough.

In sum, if one focuses on the change in the non-oil balance on goods and services and allows for a lag in the response of trade flows to exchange rate changes, the correction in the U.S. external accounts currently underway seems to belie notions of a 'disconnect' between exchange rate developments and the U.S. external accounts.

\section{Reconciling Prices And Quantities}

In this section we discuss possible explanations for the co-existence of a large U.S. current account deficit and a depreciated level of the dollar's real effective exchange rate, relative to its historical average. We focus in particular on five arguments, some of which were already 
foreshadowed in the discussion in Section III: the first relates to whether the real effective exchange rate accurately gauges U.S. "competitiveness"; the second relates to measurement problems for the U.S. current account; the third to lags in the response of trade flows to exchange rate changes, the fourth to the role of the terms of trade; and the fifth to the strength of the co-movement between the U.S. trade balance and the real effective exchange rate. ${ }^{6}$

The literature on the causes of the U.S. current account deficit and its prospects is of course much broader. For example, several authors have stressed that factors such as increasing international financial integration, a decline in home bias, the depth and liquidity of U.S. financial markets, and the general attractiveness of U.S. assets can allow the United States to run larger current account deficits than in periods of more restricted international capital mobility. ${ }^{7}$ While these arguments have intellectual appeal, they are not germane to the question this paper is asking - namely, they may explain large U.S. current account deficits but not why these deficits co-exist with a depreciated dollar exchange rate. ${ }^{8}$

\section{A. Is the REER Mismeasured? The WARP Argument}

A recent paper by Thomas, Marquez, and Fahle (2008) points out a weakness in commonly used real effective exchange rate indices. These (chain-weighted) indices take into account shifts in the patterns of international trade only partially - that is, they incorporate the effect of changes in trade weights on the weighted average of price and exchange rate changes in trading partners, but do not incorporate the impact of shifts in trade weights on the (weighted) average price level in trading partners. ${ }^{9}$ In the specific case of the United States, there has been a significant increase in the weight of emerging market trading partners since the early 1990s, reflecting the growing importance of U.S. trade with China, India, and Mexico, and a corresponding decline in the relative importance of trade with advanced economies (such as Japan). Because price levels in emerging market trading partners are lower than in advanced economies, an index of international relative prices based on relative price levels will show a more appreciated dollar than a chain-weighted real effective exchange rate index.

\footnotetext{
${ }^{6}$ We do not discuss one additional "mechanical” explanation-namely, that a trend worsening in the U.S. trade balance at a constant real effective exchange rate is explained by U.S. imports being more responsive to U.S. growth than U.S. exports are to trading partners' growth (the so-called Houthakker-Magee asymmetry).

${ }^{7}$ See, for example, Cooper (2008).

${ }^{8}$ Chinn and Lee (2008) use a simple structural VAR framework to look at the empirical relationship between the U.S. current account balance and the dollar's real effective exchange rate. They find that this relation holds better in recent years when the U.S. current account balance is measured net of official inflows, and suggest that these inflows may therefore be behind the anomalous relationship between the current account and the real exchange rate in recent years.

${ }^{9}$ The correlation between relative price levels and GDP per capita is well known in the literature, following the pioneering work of Kravis and Lipsey $(1983,1988)$. The contribution of Thomas et al. consists in documenting the importance of the effect of shifts in trading partners for the United States' relative price level and in showing that their preferred measure of international relative prices displays a stronger correlation with U.S. trade patterns than traditional real effective exchange rate measures.
} 
Figure 3 compares the behavior of the Federal Reserve Board's real effective exchange rate index (REER) with the "weighted average relative price” (WARP) index constructed by Thomas et al. These series behave very similarly throughout the 1980s, reflecting the fact that shifts in trading partners during this period did not imply significant changes in relative price levels over and above those captured by chain-weighted indices. However, since the early-to-mid-1990s the WARP series appreciates more sharply than the real effective exchange rate series, reflecting the increasing weight of low-cost producers among U.S. trading partners. As a consequence, by the last quarter of 2007 the "unwinding" of the WARP's 1995-2002 real appreciation was only partial, with the index still 8 percent above its level in the mid-1990s. As shown in Thomas et al. (2008), the WARP index does indeed track the behavior of U.S. net exports more accurately than the REER index. Chart 4 plots the non-oil balance of goods and services and the WARP index (with a 2-year lag). The correlation between the two series is -0.83 , while the correlation with the real effective exchange rate index is -0.67 .

While the measurement of price levels is notoriously fraught with problems, the point that conventional real effective exchange rate indices do not fully reflect changes in international relative prices, particularly at times of rapid changes in the geographical composition of trade is clearly correct, and the evidence of a strong co-movement of the WARP index with trade flows for the United States seems quite compelling. Looking forward, it will be interesting to ascertain whether there are significant differences between REER and WARP indices for other countries, and whether WARP-type indices show a tighter link with trade flows.

\section{B. Is The U.S. Current Account Deficit Overstated?}

The literature discussed in this section takes as starting point a striking stylized fact: during the period 1980-2007, the cumulative value of the U.S. current account deficit-a close proxy for cumulative net borrowing by the United States - totaled US\$6.7 trillion. However, during the same period the U.S. net external position deteriorated by only US\$2.8 trillion. The lion share of this stock-flow gap occurred in the past few years (Table 4): indeed, the U.S. net external position at end-2007 (as a share of GDP) is virtually unchanged since 2001, despite current account deficits averaging 5.3 percent of GDP between 2002 and 2007.

A burgeoning literature has attempted to explain this discrepancy. The aspect of this literature that is relevant for this paper concerns the sustainability of U.S. current account deficits. To the extent that the United States can run significant 'recorded' current account deficits without experiencing any deterioration in its net external position, there is no need for an adjustment in the dollar's real effective exchange rate. This point is made, for example, by Hausmann and Sturzenegger (2007) — in their view, the fact that the United States still runs a positive investment income balance and that this balance has not deteriorated significantly implies that the U.S. is de facto not a net debtor.

Understanding the reasons for this discrepancy between U.S. net external borrowing and the

change in net external liabilities is crucial in establishing whether recent trends can be safely extrapolated to the future. Authors such as Gourinchas and Rey (2007a, b) and Lane and 
Milesi-Ferretti $(2005,2007)$ among others, have emphasized the role of favorable "valuation effects" (changes in the value of external assets and liabilities driven by fluctuations in asset prices and exchange rates) in explaining the stock-flow discrepancy. Since 2001, foreign equity prices in local currency have risen faster than U.S. equity prices, increasing the value of U.S. assets more than the value of U.S. liabilities, and the significant dollar depreciation has further raised the dollar value of U.S. assets overseas denominated in foreign currencies (Table 4).$^{10}$ As a result, the rate of return earned by U.S. residents on foreign assets has in recent years significantly exceeded the rate of return earned by foreigners on their U.S. assets, offsetting the very large U.S. trade deficit (recall equation (2) in Section II).

However, this evidence does not imply that, going forward, it is realistic to project a return differential large and persistent enough to prevent the U.S. external position from deteriorating at the current and projected levels of the U.S. trade and current account deficits, absent further dollar depreciation. Exchange-rate-driven capital gains would disappear if the dollar stabilizes, and there is no evidence of a longer-term underperformance of U.S. asset prices, such as equity, relative to those in the rest of the world. Still, the U.S. may still enjoy some favorable (if more modest) return differential, for two reasons:

- It has historically earned much higher measured returns on its foreign direct investment (FDI) abroad than nonresidents have earned on their FDI in the United States; ${ }^{11}$

- The stock of U.S. equity assets (portfolio and FDI) comprises (as of end-2007) just under half of total U.S. external assets, while equity liabilities are only around 28 percent of total liabilities. Because equity-type assets tend to earn a higher rate of return than debttype assets, this implies some favorable portfolio composition-driven return differential in favor of the United States.

Taken together, however, these factors could generate an overall return differential between U.S. external assets and liabilities of 1 to $1 \frac{1}{2}$ percent-much smaller than in past years and, given external assets of around 100 percent of GDP, clearly insufficient to offset a trade deficit of 4-5 percent of GDP. ${ }^{12}$

\footnotetext{
${ }^{10}$ This effect has been amplified by the steeper decline of the U.S. dollar relative to the currencies of its main financial trade partners (mostly advanced economies) than relative to its goods and services' trading partners (Figure 1).

${ }^{11}$ The FDI yield differential over the past decade (calculated on the basis of current-cost estimates) was 51/2 percent. An extensive literature discusses potential explanations for this differential (see, for example, Mataloni, 2000).

${ }^{12}$ With a 4 percent additional return on equity instruments relative to debt instruments, and assuming the same return on domestic and foreign equity and debt holdings, the "portfolio composition" effect generates a return differential of about $3 / 4$ percent. Adding to this a difference in FDI returns equal to its (very high) average over the past decade raises the overall return differential by a similar amount (3/4 percent) .
} 
Other papers (Curcuru, Dvorak, and Warnock, 2008; Curcuru, Thomas, and Warnock, 2008; Lane and Milesi-Ferretti, 2008) have noted that in the case of the United States the return differential between U.S. external assets and liabilities calculated from balance of payments data may overstate the actual differential. Specifically, realistically estimated capital gains from exchange rate and asset price valuation effects can account for only a portion of the total stock-flow discrepancy, with the remainder likely reflecting measurement problems in both stocks and flows. In terms of the decomposition presented in Table 4, this implies that a significant component of "other changes" captures measurement error in net financial flows, as well as — to a lesser extent-measurement error in the external position. The evidence presented in these papers suggests that net external borrowing by the United States as well as the U.S. trade deficit may be slightly overstated (by around $1 / 4$ to $1 / 2$ percentage point of GDP a year), as well as convincingly making the point that return differentials in recent years, while high, have been below those measured from balance of payments data.

Looking forward, the evidence that the U.S. current account deficit may be slightly overstated - together with the rate of return projections described above-does not overturn the basic finding that "measured" trade deficits of 4-5 percent of GDP would over time imply a significant deterioration in the U.S. external position. A sober assessment of the prospects for the U.S. external position along these lines is provided by Bertaut, Kamin, and Thomas (2008): based on a large-scale partial-equilibrium model of the U.S. balance of payments, they conclude that U.S. net external liabilities could reach 60 percent of U.S. GDP by 2020 (from their end-2007 level of around 20 percent of GDP).

\section{Adjustment Lags}

As foreshadowed in Section III, the response of trade flows to changes in international relative prices typically occurs with significant lags - the so-called J-curve suggests that a depreciation will initially worsen the trade balance because of the effect of higher import prices, and then gradually strengthen it, as quantities adjust. Figure 6 shows the crosscorrelogram of the U.S. non-oil trade balance (the ratio of the balance of goods and services net of petroleum products to GDP) and the real effective exchange rate (in log terms) at a quarterly frequency. For both unfiltered data (panel A) and HP-filtered cyclical data (panel B) the correlation peaks at a lag of about 8 quarters. A substantial body of empirical evidence on U.S. data corroborates this stylized fact (see, for example, Marquez, 1991, Hooper, Johnson, and Marquez, 2000 and Thomas, Marquez, and Fahle, 2008). ${ }^{13}$

As of end-September 2008, the average real effective exchange rate for the dollar during 2008 was over 10 percent more depreciated than during 2006. In light of the evidence on lags, this suggests that - at the current real effective value of the dollar — a further relative

\footnotetext{
${ }^{13}$ The low rate of pass-through of exchange rates on U.S. import prices has often been mentioned in the literature as a factor impeding or at least delaying an adjustment of the U.S. trade balance. However, the effect of a low pass-through of exchange rate changes on U.S. import prices is ambiguous - when the dollar depreciates import volumes will not adjust if import prices fail to rise, but at the cost of imports is also lower. For a general discussion, see Goldberg and Wiske-Dillon (2007).
} 
price-driven improvement in the U.S. trade balance is to be expected, other things being equal.

\section{The Terms of Trade and Oil Prices}

As discussed in Section II, higher oil prices have played an important role in explaining the deterioration of the U.S. trade balance over the past decade (see, for example, Table 2). Figure 5 shows the behavior of the terms of trade and oil prices since 1973-since the U.S. is a net oil importer, there is a clear negative relation between the two series (see Backus and Crucini, 2000). ${ }^{14}$ Indeed, in light of the record-high oil prices of the first half of 2008, the U.S. terms of trade are at their lowest level for the past 6 decades, and some 11 percent below their average for the 1973-2008 period.

A decline in the U.S. terms of trade can of course reflect shocks of a different nature. Because U.S. export prices are primarily set in U.S. dollars and some import prices are set in foreign currency, a nominal depreciation of the dollar will tend to worsen the terms of trade. ${ }^{15}$ To the extent that the real effective depreciates, the deterioration in the terms of trade may be associated in the short run with a worsening balance of goods and services but (with a lag) with an improvement in that balance. On the other hand, a deterioration in the terms of trade may reflect an increase in import prices set on world markets (for example, commodity prices) driven by global demand or supply shocks. If demand for these goods is price inelastic, especially in the short run, this shock would — ceteris paribus - be associated with a deterioration in the balance of goods and services both in the short and the medium run. Under these circumstances, maintaining a stable external balance would require a more depreciated real effective exchange rate.

Consistent with this latter line of reasoning, the literature on "commodity currencies" finds a very strong link between real effective exchange rates and commodity prices (see Chen and Rogoff, 2003 for advanced economies and Cashin, Céspedes, and Sahay, 2004 for emerging markets). A related literature finds that the "commodity terms of trade" (defined as the relative price of a country's commodity exports to commodity imports, taking into account their relative weight in the country's trade) are an important determinant of real effective exchange rates in a much wider sample of countries (see, for example, Ricci, Milesi-Ferretti, and Lee, 2008). For the case of the United States, the weak terms of trade associated with high oil and other commodity prices help explain the co-existence of a large U.S. trade deficit with a depreciated real effective exchange rate of the dollar.

\footnotetext{
${ }^{14}$ The terms of trade are measured as the ratio of the deflator for exports and goods and services to the deflator for imports and goods and services, while oil prices are measured as the average of three oil prices (U.K. Brent, Dubai Fateh, and Texas Intermediate), divided by the U.S. GDP deflator.

${ }^{15}$ For a recent discussion of pass-through of nominal exchange rate changes on import prices, see Goldberg and Campa (2008).
} 


\section{E. External Adjustment and Shift in Relative Prices}

A final argument we consider is the possibility that significant shifts in the balance on goods and services can occur even with relatively modest shifts in U.S. relative prices. As discussed in Obstfeld and Rogoff (2007), the size of the change in relative prices that would be associated with a reduction in the U.S. current account depends on the degree of factor mobility across sectors (and across countries). With labor relatively immobile across sectors (as is likely the case in the short run) the change in relative prices associated with U.S. current account rebalancing would be quite substantial. Indeed, macroeconomic estimates of "trade elasticities" from partial-equilibrium econometric exercises typically find that the response of the volume of trade flows to relative price changes is not very strong, with a standard "rule of thumb" suggesting that a 1 percent improvement in the U.S. trade balance is associated with a real depreciation of the U.S. dollar of close to 10 percent. ${ }^{16}$ At the same time, microeconomic studies typically find a much stronger response of exports and imports to relative price shifts.

In a recent theoretical contribution, Corsetti, Martin, and Pesenti (2008) have focused on a different factor that can affect the size of the needed relative price shift for current account rebalancing - the so-called "extensive margin" of trade. The authors point out that trade in new product varieties (the extensive margin of trade) accounts for a significant fraction of trade growth, while most models focus on trade in existing products (the "intensive margin"). They then construct a model where varieties of goods are created and destroyed as a consequence of shifts in aggregate demand across countries, in addition to more standard features of models of the transfer problem. They find that when endogenous new varieties are present the deterioration in the terms of trade and real exchange rate associated with a significant reduction in the current account deficit is much more modest than in a model with fixed varieties. ${ }^{17}$

While the emphasis on the extensive margin of trade is a priori quite important and relevant, a key issue is the quantitative relevance of this factor as well as the horizon at which the channel identified by the authors is operating - an important area for future research. Some preliminary evidence on this issue is presented in Galstyan and Lane (2008). These authors investigate the relative importance of the intensive and extensive margin in explaining the evolution of trade flows in large deficit and surplus countries over a relatively short period (2001-2004), and find an important role for the extensive margin, particularly for China and the United States.

\footnotetext{
${ }^{16}$ This would be the case, for example, with a unitary elasticity of export and import volumes with respect to real effective exchange rate changes. A simple regression of the U.S. non-oil balance of goods and services as a share of GDP on the lagged real effective exchange rate (in logs) and real domestic and foreign output suggests that a 10 percent real depreciation is eventually associated with an improvement in the trade balance of over 1 percent of GDP.

${ }^{17}$ See also Dekle, Eaton, and Kortum (2007) for a quantitative model of bilateral trade that implies small relative price adjustments to achieve a reduction in global current account imbalances.
} 


\section{CONCLUSions}

We have presented a variety of arguments that help address the "fundamentals at odds" puzzle. While understanding exchange rate fluctuations is notoriously difficult, and none of these arguments can by itself explain the puzzle, taken together they provide a reasonable reconciliation of the co-movement between the dollar's real effective exchange rate and the U.S. trade balance.

In terms of explaining the depreciated value of the dollar's real effective exchange rate associated with the large U.S. trade deficit we have underscored two arguments, one related to the measurement of the real effective exchange rate and the other related to fundamental factors affecting its value. With regard to measurement, the change in the composition of U.S. trading partners towards low-price producers may imply that traditional real effective exchange rate indices will overstate the decline in the dollar, because they do not incorporate the declining average prices in trading partners. With regard to the fundamentals affecting the dollar's real effective exchange rate, the significant deterioration in the terms of trade driven by the commodity price boom is an important factor in explaining the co-existence of a depreciated value of the dollar and a large trade deficit.

In terms of the U.S. balance of goods and services, we have mentioned three general arguments. First, the composition of the U.S. external portfolio implies that on average the United States enjoys a favorable rate of return differential between external assets and liabilities, implying that the adjustment in the balance of goods and services to ensure that the U.S. external position is stabilized is smaller than would otherwise be the case. Furthermore, this effect has been reinforced by the increase in the process of international financial integration, which has boosted the size of both external assets and liabilities relative to GDP. Second, there are significant lags in the response of trade flows to exchange rate changes, thus implying that some relative-price-induced correction in the U.S. trade balance may still be in the pipeline (in light of the fact that the dollar depreciated in both 2007 and 2008). Third, there is some preliminary evidence of a possible overstatement of the U.S. trade deficit, albeit of a modest entity.

Finally, some recent research on trade flows and international relative prices suggests that, when new varieties of goods are an important component of the growth in cross-border trade, significant changes in net trade flows may be associated with only modest changes in international relative prices. In turn, this would suggest that the needed decline in the U.S. trade deficit could be achieved with only a modest real exchange rate depreciation. As the evidence on the subject is still very scant, this is an interesting area for future research. 
Table 1. Historical Patterns of U.S. Dollar Real Depreciations (1973-2008)

A. Relative to All Trading Partners

\begin{tabular}{|c|c|c|c|c|}
\hline \multirow[t]{2}{*}{ Depreciation period } & \multicolumn{2}{|c|}{ Peak-to-trough Depreciation Rate (\%) } & \multirow{2}{*}{$\begin{array}{c}\text { Duration } \\
\text { (year equivalent) }\end{array}$} & \multirow[t]{2}{*}{$\begin{array}{l}\text { Maximum } \\
\text { monthly } \\
\text { depreciation }\end{array}$} \\
\hline & overall & annual equivalent & & \\
\hline Dec 1975 - Oct 1978 & $-12.9 \%$ & $-4.7 \%$ & 2.84 & $2.1 \%$ \\
\hline Mar 1985 - Feb 1991 & $-32.3 \%$ & $-6.4 \%$ & 5.93 & $3.7 \%$ \\
\hline Feb 2002 - Mar 2008 & $-24.7 \%$ & $-4.5 \%$ & 6.09 & $3.2 \%$ \\
\hline \multicolumn{5}{|c|}{ B. Relative to Major Currencies } \\
\hline \multirow[t]{2}{*}{ Depreciation period } & \multicolumn{2}{|c|}{ Peak-to-trough Depreciation Rate (\%) } & Duration & $\begin{array}{l}\text { Maximum } \\
\text { monthly } \\
\text { depreciation }\end{array}$ \\
\hline & overall & annual equivalent & (year equivalent) & \\
\hline Dec 1975 - Oct 1978 & $-15.6 \%$ & $-5.8 \%$ & 2.84 & $2.6 \%$ \\
\hline Mar 1985 - Feb 1991 & $-39.6 \%$ & $-8.2 \%$ & 5.93 & $5.2 \%$ \\
\hline Feb 2002 - Mar 2008 & $-32.4 \%$ & $-6.2 \%$ & 6.09 & $4.7 \%$ \\
\hline
\end{tabular}

Source: author's calculations based on real effective exchange rate data from the U.S. Federal Reserve Board. 
Table 2. Historical Patterns of U.S. Dollar Nominal Depreciations (1976-2008)

\section{A. Relative to All Trading Partners}

\begin{tabular}{|c|c|c|c|c|c|c|c|}
\hline \multirow{2}{*}{ Depreciation period } & \multicolumn{2}{|c|}{$\begin{array}{c}\text { Peak-to-trough } \\
\text { Depreciation Rate (\%) }\end{array}$} & \multirow{2}{*}{$\begin{array}{c}\text { Duration } \\
\text { year } \\
\text { equivalent }\end{array}$} & \multicolumn{3}{|c|}{ Maximum depreciation (\%) } & \multirow{2}{*}{$\begin{array}{c}\text { 30-day } \\
\text { Average } \\
\text { Volatility } \\
\text { sd.dev. (\%) }\end{array}$} \\
\hline & overall & $\begin{array}{c}\text { annual } \\
\text { equivalent }\end{array}$ & & daily & 7-day & $\begin{array}{l}\text { 30- } \\
\text { day }\end{array}$ & \\
\hline 28 Jan $02-15$ July 08 & $27.1 \%$ & $4.8 \%$ & 6.47 & $0.9 \%$ & $2.0 \%$ & $3.9 \%$ & $7.8 \%$ \\
\hline
\end{tabular}

\section{B. Relative to Major Currencies}

\begin{tabular}{|c|c|c|c|c|c|c|c|}
\hline \multirow[t]{2}{*}{ Depreciation period } & \multicolumn{2}{|c|}{$\begin{array}{c}\text { Peak-to-trough } \\
\text { Depreciation Rate (\%) }\end{array}$} & \multirow{2}{*}{$\begin{array}{c}\text { Duration } \\
\text { year } \\
\text { equivalent }\end{array}$} & \multicolumn{3}{|c|}{$\begin{array}{c}\text { Maximum depreciation } \\
\text { (\%) }\end{array}$} & \multirow{2}{*}{$\begin{array}{c}\text { 30-day } \\
\text { Average } \\
\text { Volatility }\end{array}$} \\
\hline & overall & $\begin{array}{c}\text { annual } \\
\text { equivalent }\end{array}$ & & daily & 7-day & 30-day & \\
\hline 30 Nov $76-30$ Oct 78 & $18.5 \%$ & $10.1 \%$ & 1.92 & $1.2 \%$ & $2.8 \%$ & $5.6 \%$ & $8.5 \%$ \\
\hline 25 Feb 85- 11 Feb 91 & $44.3 \%$ & $9.8 \%$ & 5.96 & $2.8 \%$ & $6.3 \%$ & $7.4 \%$ & $14.1 \%$ \\
\hline 28 Jan 02- 15 July 08 & $38.0 \%$ & $7.1 \%$ & 6.47 & $1.3 \%$ & $3.1 \%$ & $6.3 \%$ & $12.9 \%$ \\
\hline
\end{tabular}

Source: author's calculations based on nominal effective exchange rate data from the U.S. Federal Reserve Board. 
Table 3. The U.S. Current Account Balance and Oil Prices During the Adjustment Episodes

\begin{tabular}{|c|c|c|}
\hline & 1980-87 & 1997-2004 \\
\hline $\begin{array}{l}\text { Change in current account balance (percent of GDP) } \\
\text { of which }\end{array}$ & -3.5 & -3.8 \\
\hline change in non-oil balance on goods and services & -4.3 & -3.3 \\
\hline change in oil balance & 1.8 & -0.7 \\
\hline change in income balance & -0.8 & 0.3 \\
\hline change in transfers & -0.2 & -0.2 \\
\hline change in real effective exchange rate (t-2) $1 /$ & 34.1 & 24.6 \\
\hline change in U.S. output gap & 1.9 & -0.3 \\
\hline change in output gap in trading partners $2 /$ & -2.0 & -0.5 \\
\hline & 1987-91 & 2004-08 \\
\hline $\begin{array}{l}\text { Change in current account balance (percent of GDP) } \\
\text { of which }\end{array}$ & 3.4 & 1.1 \\
\hline change in non-oil balance on goods and services & 2.6 & 2.1 \\
\hline change in oil balance & 0.1 & -1.3 \\
\hline change in income balance & 0.1 & 0.3 \\
\hline change in transfers & 0.7 & 0.0 \\
\hline Change in real effective exchange rate (t-2) $1 /$ & -26.9 & -13.6 \\
\hline Change in U.S. output gap & -2.2 & -2.0 \\
\hline Change in output gap in trading partners $2 /$ & 1.9 & 0.5 \\
\hline
\end{tabular}

1 / log change in the real effective exchange rate between 1978-85, 1985-89, 1995-2002, and 2002-2006 respectively. Source: Federal Reserve Board.

2/trading partners comprise advanced economies only.

Source: IMF, World Economic Outlook and author's calculations. 
Table 4. Cumulative Financial Flows and Changes in the U.S. International Investment Position 1/

1989-1995 1995-2001 2001-2007

Cumulative financial flows + Cumulative asset price effects + Cumulative exchange rate valuation effects + Cumulative "other changes" = Change in international investment position
$-530$

$-111$

36

343

$-262$
$-1,537$

$-28$

$-499$

618

$-1,446$
$-3,880$

1,379

1,061

866

$-573$

1/ Billions of U.S. dollars. The net international investment position is measured with FDI at current cost. "Other" changes include "changes in coverage due to year-to-year changes in the composition of reporting panels, primarily for bank and nonbank estimates, and to the incorporation of survey results. Also includes capital gains and losses of direct investment affiliates and changes in positions that cannot be allocated to financial flows, price changes, or exchange-rate changes.” Source: Bureau of Economic Analysis. 
Figure 1. Real Effective Exchange Rate, January 1973-September 2008

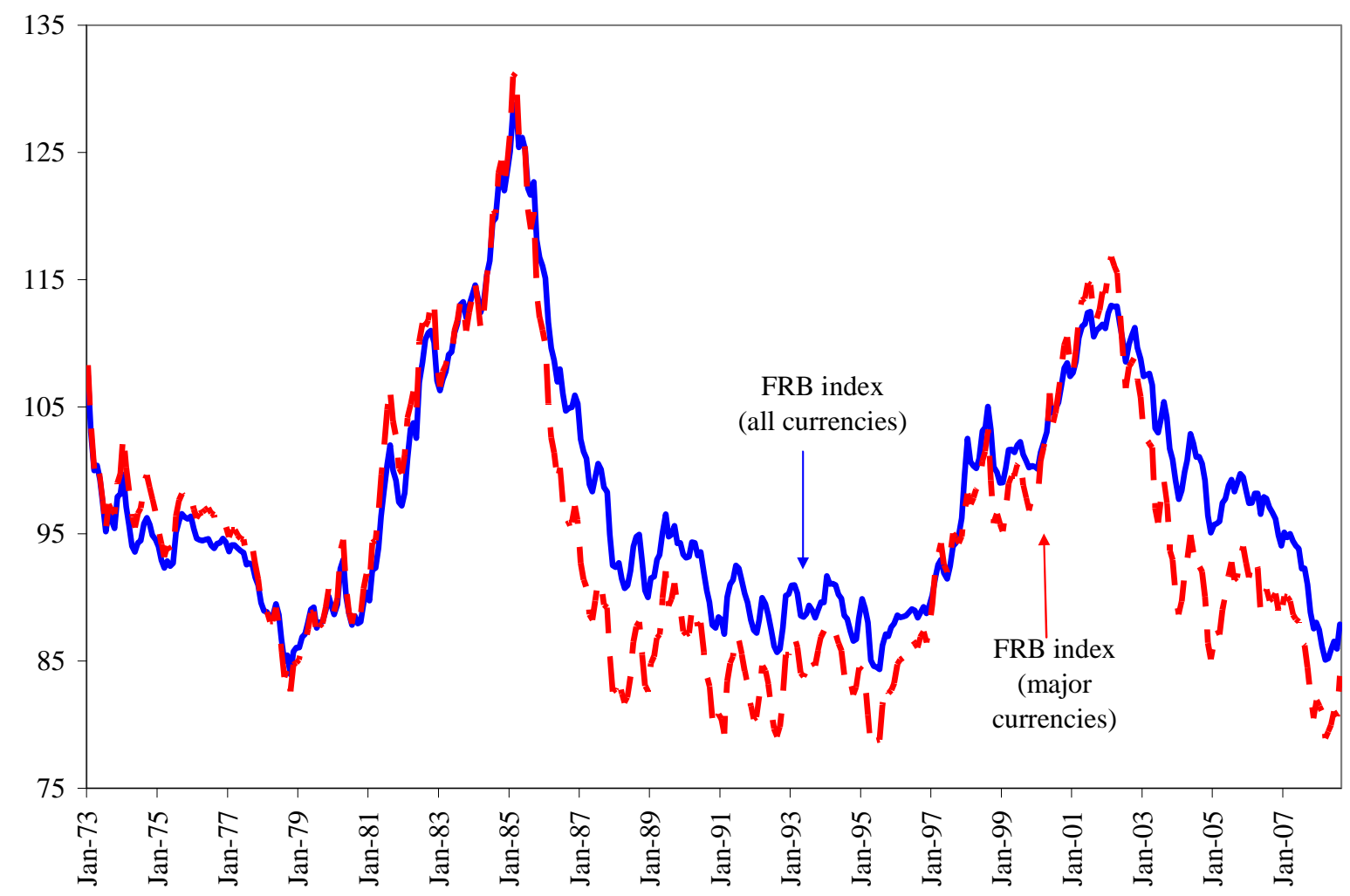

Source: U.S. Federal Reserve Board. 
Figure 2. Current Account Balance and Non-Oil Balance on Goods and Services (ratio of GDP, 1970Q1-2008Q2)

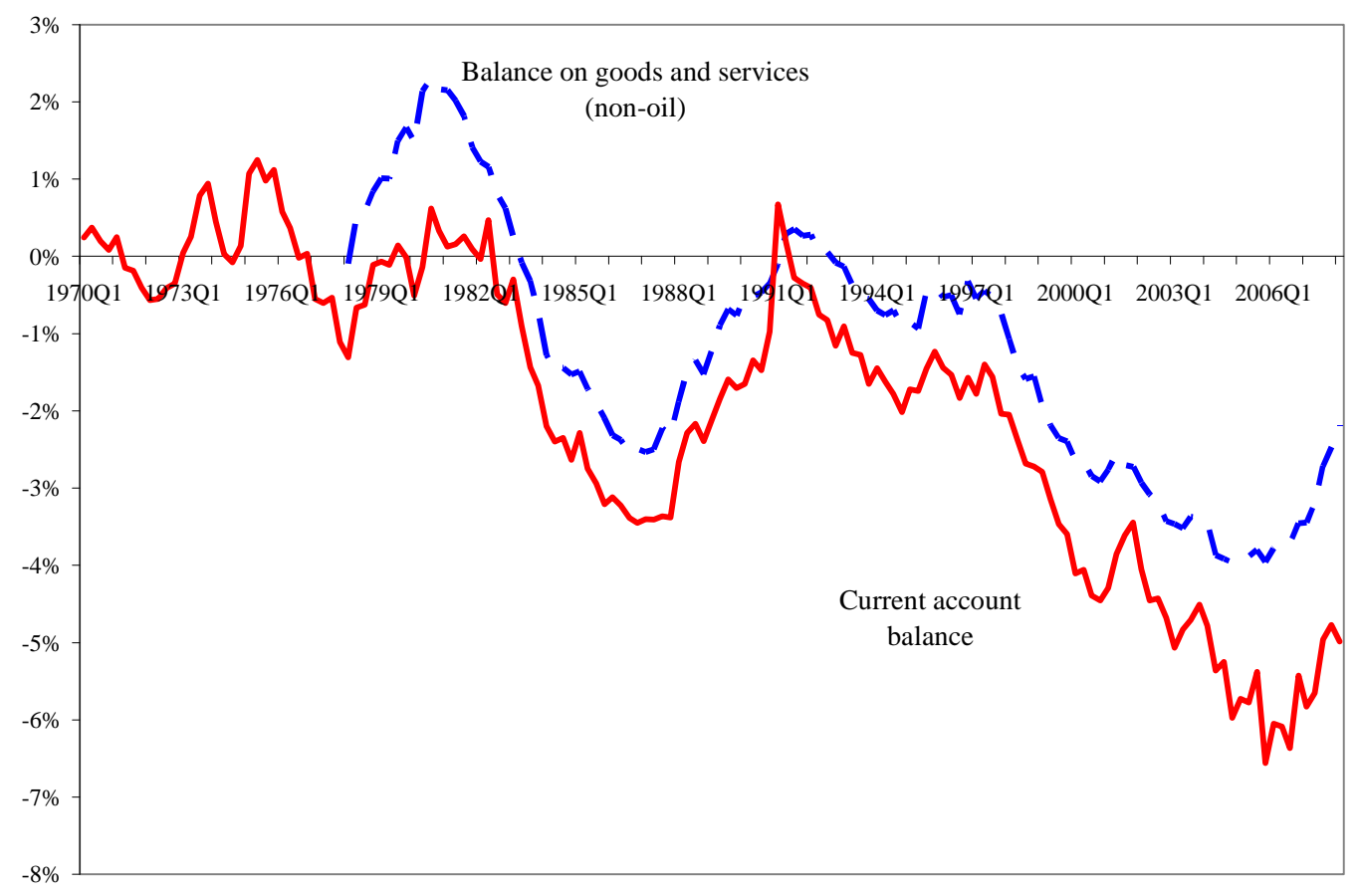

Source: U.S. Bureau of Economic Analysis. 
Figure 3. Real Effective Exchange Rate and “WARP” Index

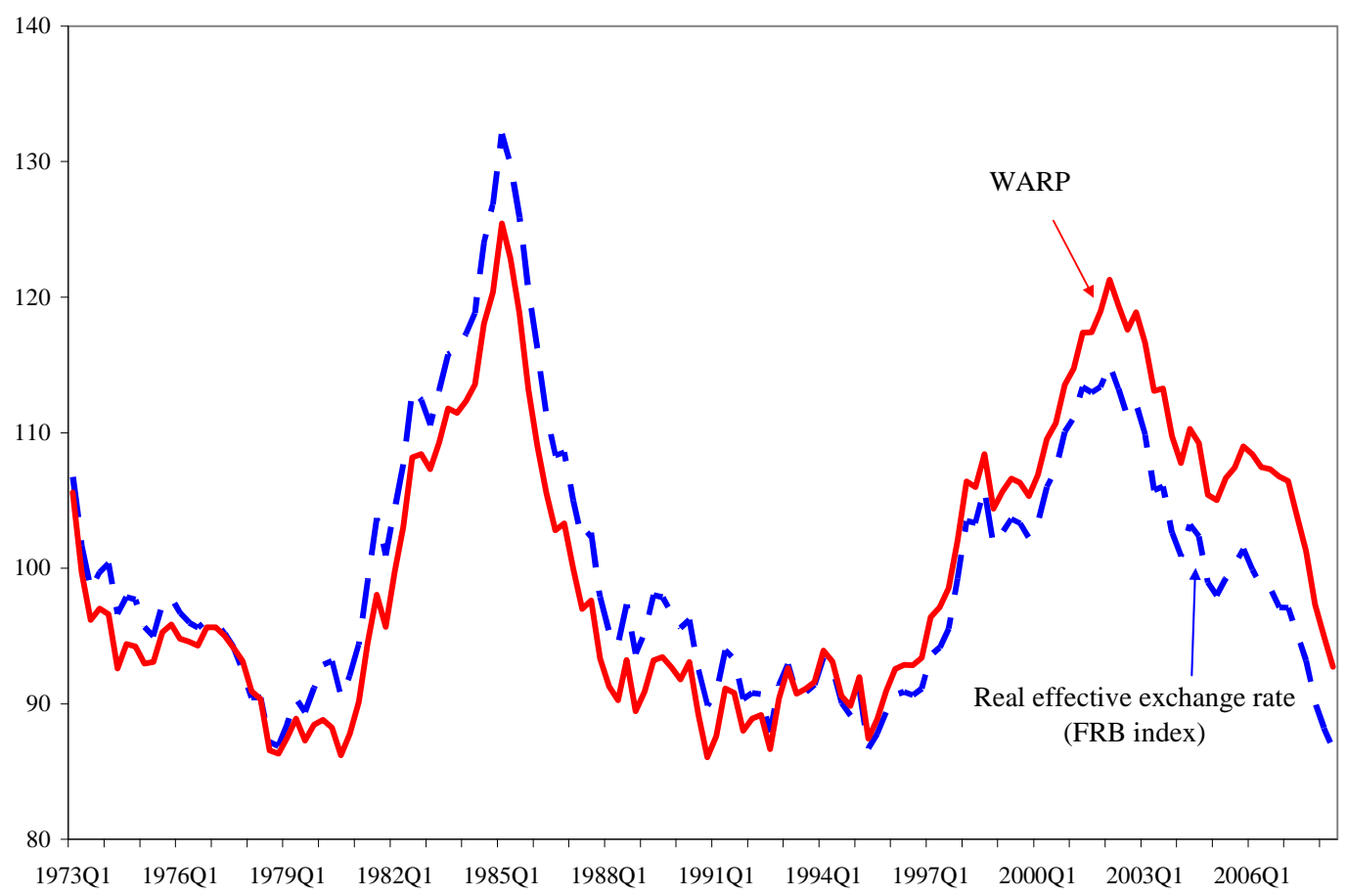

Sources: Thomas, Marquez, and Fahle (2008) and U.S. Federal Reserve Board. 
Figure 4. Lagged "WARP” Index and Non-Oil Balance of Goods and Services

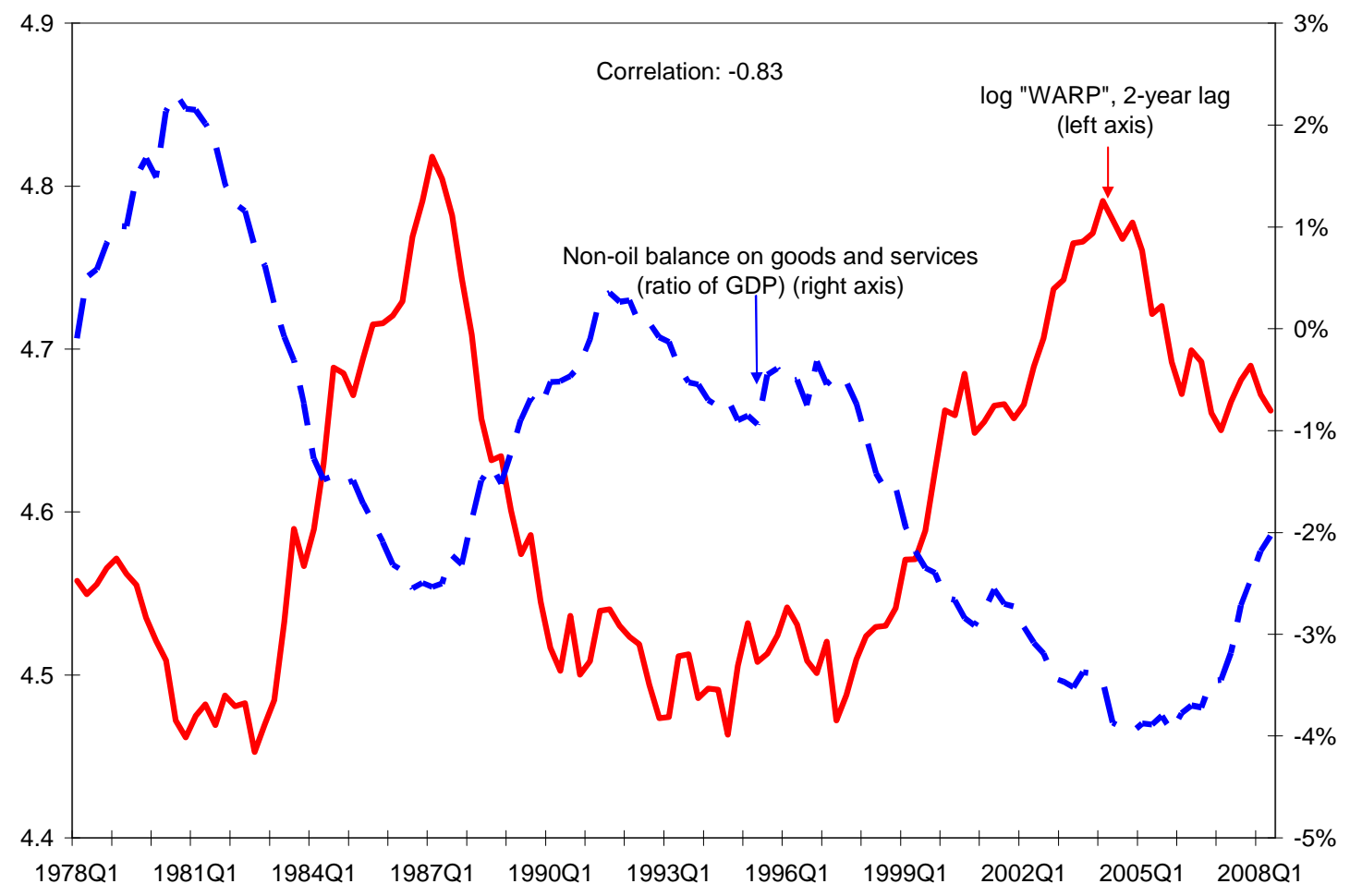

Sources: Thomas, Marquez, and Fahle (2008), U.S. Federal Reserve Board, and U.S. Bureau of Economic Analysis. 
Figure 5. Non-Oil Trade Balance and Real Exchange Rate:

Cross-Correlation (1978Q1-2008Q2)

A. Unfiltered data

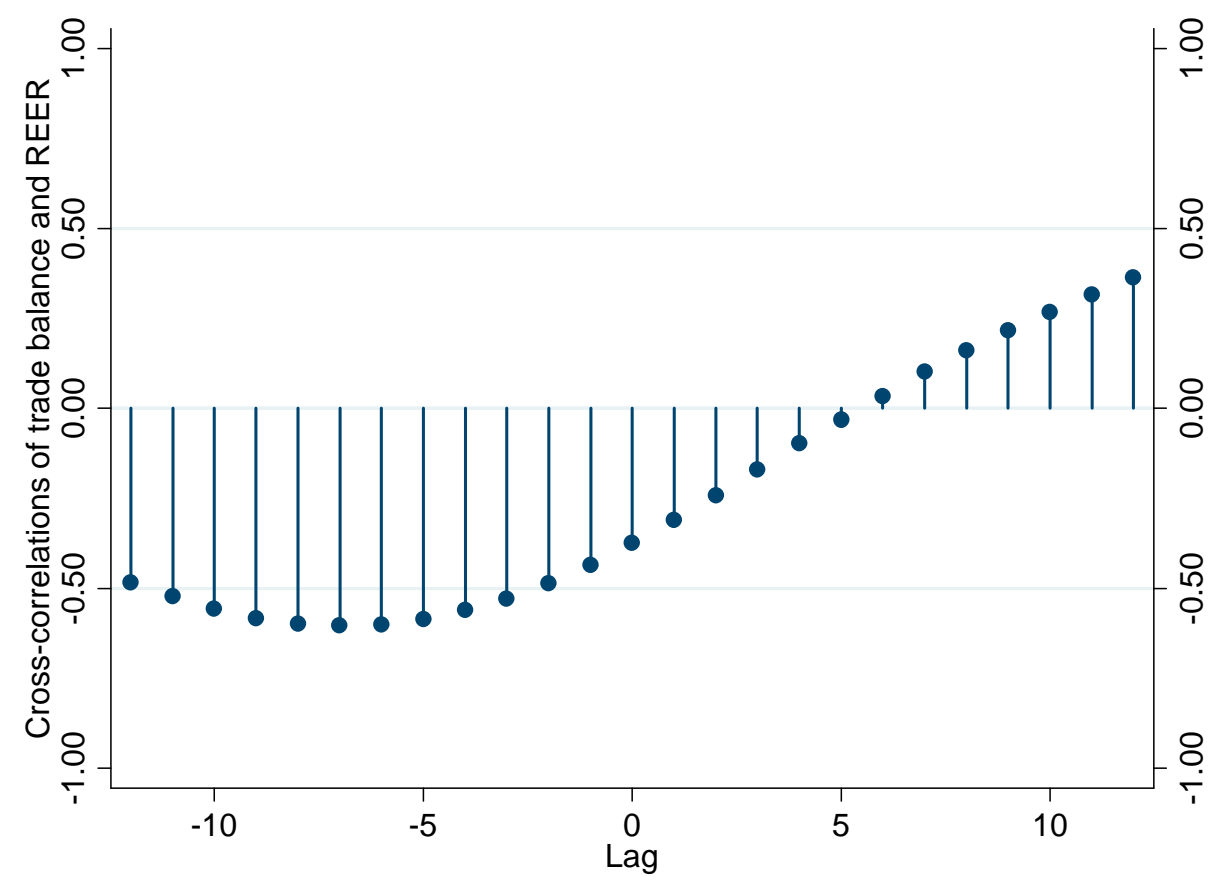

B. HP-filtered data (cyclical component)

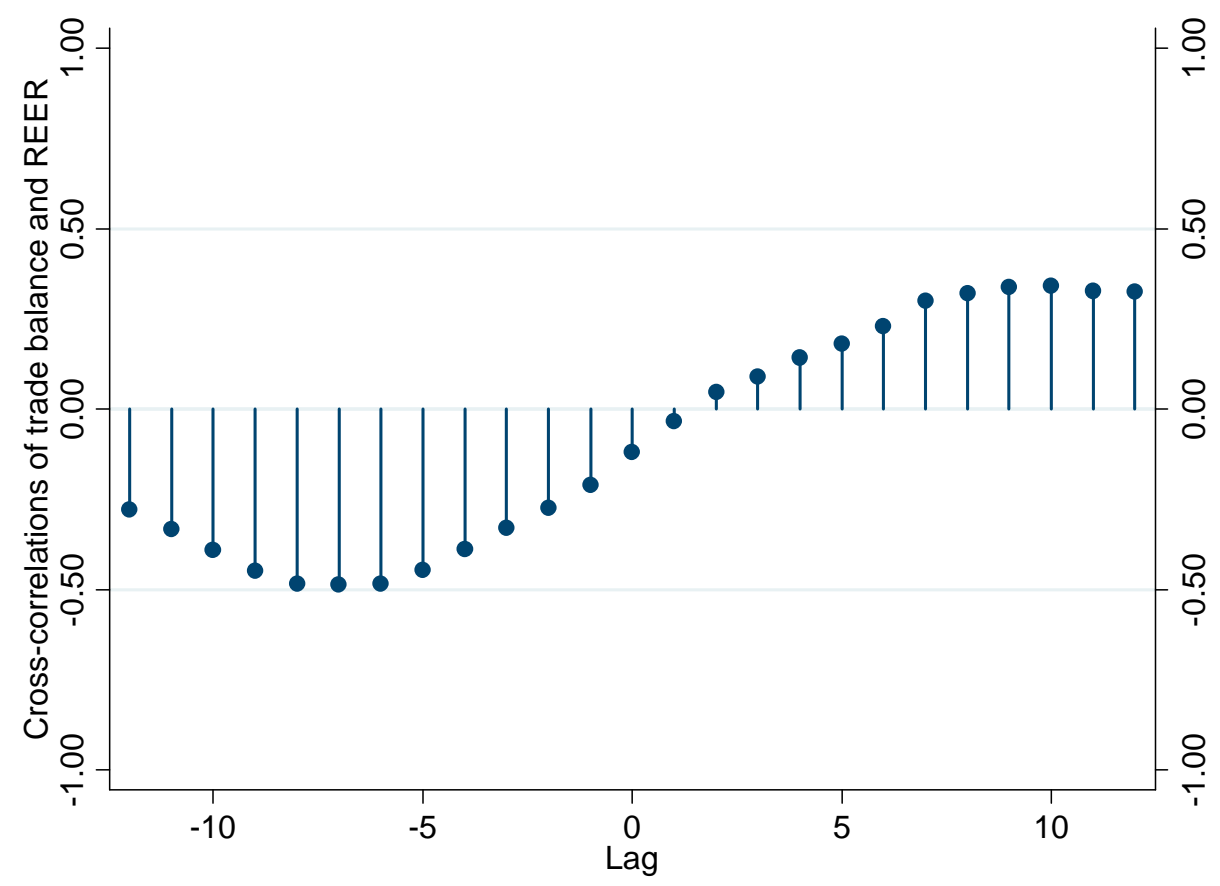

Note: balance of goods and services excluding oil (in percent of GDP) and CPI-based real effective exchange rate (log terms). Sources: Bureau of Economic Analysis and FRB. 
Figure 6. Terms of Trade and Oil Prices, 1973-2008

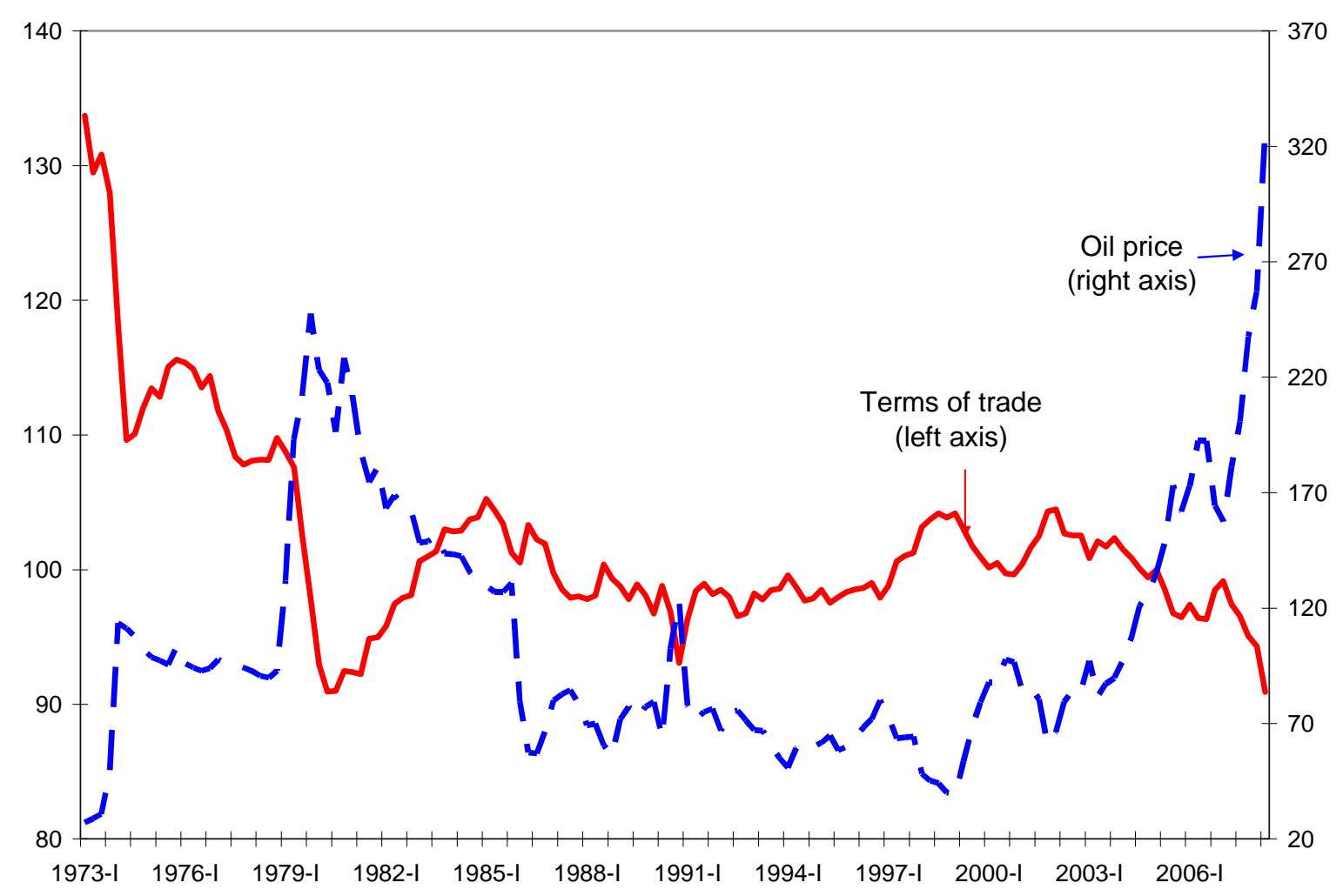

Note: the terms of trade are measured as the ratio of the deflator for exports of goods and services to the deflator for imports of goods and services. The oil price is the ratio of the average price of Texas Intermediate, U.K. Brent, and Dubai Fateh to the U.S. GDP deflator. Sources: U.S. Bureau of Economic Analysis and IMF, International Financial Statistics. 


\section{REFERENCES}

Backus, David, and Mario Crucini, 2000, “Oil Prices and the Terms of Trade,” Journal of International Economics, Vol. 50 (February), pp. 185-212.

Bertaut, Carol, Steve Kamin, and Charles Thomas, 2008, "How Long Can The Unsustainable U.S. Current Account Deficit Be Sustained?,” Federal Reserve Board, International Finance Discussion Paper 935 (July).

Blanchard, Olivier, Francesco Giavazzi, and Felipa Sa, 2005, "International Investors, the U.S. Current Account, and the Dollar”, Brookings Papers on Economic Activity, Vol. 1, pp. 1-49.

Cashin, Paul, Luis F. Céspedes, and Ratna Sahay, 2004, “Commodity Currencies and The Real Exchange Rate,” Journal of Development Economics, Vol. 75, pp. 239-68.

Chen, Yu-Chin and Kenneth Rogoff, 2003, “Commodity Currencies,” Journal of International Economics, Vol. 60 (May), pp. 133-60.

Chinn, Menzie and Jaewoo Lee, 2008, “Three Current Account Balances: A "SemiStructuralist” Interpretation,” Japan and the World Economy, forthcoming.

Cooper, Richard N., 2008, “Global Imbalances, Demography, and Sustainability,” Journal of Economic Perspectives, Vol. 22, No. 3, pp. 93-112.

Corsetti, Giancarlo, Philippe Martin, and Paolo Pesenti, 2008, "Varieties and the Transfer Problem: The Extensive Margin of Current Account Adjustment,” CEPR Discussion Paper 6660.

Croke, Hilary, Steven Kamin, and Sylvain Leduc, 2006, “An Assessment of the Disorderly Adjustment Hypothesis for Industrial Economies,” International Finance, Vol. 9 (Spring), pp. 37-61.

Curcuru, Stephanie E., Tomas Dvorak, and Francis E. Warnock, 2008, “Cross-Border Return Differentials,” Quarterly Journal of Economics 123 (4), pp. 1495-1530.

Curcuru, Stephanie E., Charles P. Thomas and Francis E. Warnock, 2008, “Current Account Sustainability and The Relative Reliability of the International Accounts,” NBER Working Paper No. 14295.

Dekle, Robert, Jonathan Eaton and Samuel Kortum, 2007, “Unbalanced Trade,” American Economic Review Papers and Proceedings, Vol. 97, No. 2, pp. 351-355. 
Dooley, Michael, Peter Garber and David Folkerts-Landau, 2005, "Is it 1958 or 1968? Three Notes on The Longevity of the Bretton Woods System,” Brookings Papers on Economic Activity, Vol. 1, pp. 147-209.

Edwards, Sebastian, 2005, "Is the U.S. Current Account Deficit Sustainable? If Not, How Costly Is Adjustment Likely to Be?” Brookings Papers on Economic Activity, Vol. 1, pp. 211-71.

Engel, Charles and John Rogers, 2006, “The U.S. Current Account Deficit and The Expected Share of World Output,” Journal of Monetary Economics, Vol. 53, pp. 1063-93.

Faruqee, Hamid, Douglas Laxton, Dirk Muir, and Paolo Pesenti, 2007, "Smooth Landing or Crash? Model-Based Scenarios of Global Current Account Rebalancing,” in Richard H. Clarida, editor, G7 Current Account Imbalances: Sustainability and Adjustment, University of Chicago Press, pp. 377-456.

Fratzscher, Marcel, Luciana Juvenal, and Lucio Sarno, 2007, “Asset prices, Exchange Rates and the Current Account,” European Central Bank, Working Paper No. 790 (July).

Freund, Caroline and Frank E. Warnock, 2007, “The Bigger They Are, the Harder They Fall?” in Clarida, R. (ed.) G7 Current Account Imbalances: Sustainability and Adjustment, The University of Chicago Press, pp. 133-62.

Galstyan, Vahagn and Philip R. Lane, 2008, "External Imbalances and the Extensive Margin of Trade,” IIIS Discussion Paper 259.

Goldberg, Linda and José Manuel Campa, 2008, “The Insensitivity of the CPI to Exchange Rates: Distribution Margins, Imported Inputs, and Trade Exposure,” forthcoming, Review of Economics and Statistics.

Goldberg, Linda and Eleanor Wiske Dillon, 2007, "Why a Dollar Depreciation May Not Close the U.S. Trade Deficit," Current Issues in Economics and Finance, Vol. 13, No. 5 (June).

Gourinchas, Pierre-Olivier and Hélène Rey, 2007a, "From World Banker to World Venture Capitalist: US External Adjustment and the Exorbitant Privilege”, in Clarida, R. (ed.) G7 Current Account Imbalances: Sustainability and Adjustment, The University of Chicago Press, pp. 11-55.

— , 2007b, “International Financial Adjustment," Journal of Political Economy, Vol. 115, No. 4 (August), pp. 665-703.

Hausmann, Ricardo and Federico Sturzenegger, 2007, “Global Imbalances or Bad Accounting? The Missing Dark Matter in the Wealth of Nations and Its Implications for Global Imbalances,” Economic Policy, Vol. 51 (July), pp. 469-518. 
Hooper, Peter, Karen Johnson, and Jaime Marquez, 2000, “Trade Elasticities for G-7 Countries,” Princeton Studies in International Economics, Vol. 87 (August).

Kamin, Steve, Trevor A. Reeve, and Nathan Sheets, 2007, “U.S. External Adjustment: Is It Disorderly? Is It Unique? Will It Disrupt the Rest of the World?,” International Finance Discussion, Paper 892 (Board of Governors of the Federal Reserve System).

Kravis, Irving B. and Robert E. Lipsey, 1983, “Toward an Explanation of National Price Levels,” Princeton Studies in International Finance, No. 52 (November).

_ 1988 , "National Price Levels And The Prices Of Tradables And Nontradables," American Economic Review, Vol. 78, No. 2, pp. 474-78.

Krugman, Paul, 1991, “Has The Adjustment Process Worked?” Policy Analyses in International Economics, Vol. 34, Institute for International Economics.

Krugman, Paul, 2007, “Will There Be a Dollar Crisis?,” Economic Policy, Vol. 51 (July), pp. 435-67.

Lane, Philip R. and Gian Maria Milesi-Ferretti, 2005, "Financial Globalization and Exchange Rates,” IMF Working Paper 05/03 (January).

— G7 Current Account Imbalances: Sustainability and Adjustment, University of Chicago Press, pp. 67-98.

— 2008, "Where Did All The Borrowing Go? A Forensic Analysis of the U.S. External Position,” IMF Working Paper 08/28 (forthcoming, Journal of the Japanese and International Economies).

Laxton, Douglas and Gian Maria Milesi-Ferretti, 2005, "How Will Global Imbalances Adjust?”, World Economic Outlook (Fall), Appendix 1.2 (Washington, D.C.: International Monetary Fund).

Lawrence, Robert Z., 1990, “U.S. Current Account Adjustment: An Appraisal,” Brookings Papers on Economic Activity, Vol. 2, pp. 343-82.

Marquez, Jaime, 1991, “The Dynamics of Uncertainty or the Uncertainty of Dynamics: Stochastic J-Curves,” Review of Economics and Statistics, Vol. 73, pp. 125-33.

Mataloni, Raymond, 2000, “An Examination of the Low Rates of Return of Foreign-Owned U.S. Companies,” Survey of Current Business, March, pp. 55-73.

Obstfeld, Maurice and Kenneth Rogoff , 2001, "Perspectives on OECD Economic Integration: Implications for US Current-Account Adjustment,” in Global Economic 
Integration: Opportunities and Challenges, Federal Reserve Bank of Kansas City, Annual Monetary Policy Symposium, pp. 169-208.

_ , 2005, "Global Current Account Imbalances and Exchange Rate Adjustments," Brookings Papers on Economic Activity, Vol. 1, pp. 67-123.

— , 2007, “The Unsustainable U.S. Current Account Deficit Revisited,” in Richard H. Clarida, editor, G7 Current Account Imbalances: Sustainability and Adjustment, University of Chicago Press, pp. 339-66.

Ricci, Luca Antonio, Gian Maria Milesi-Ferretti, and Jaewoo Lee, 2008, "Real Exchange Rates and Fundamentals: A Cross-Country Perspective,” IMF Working Paper 08/13, (January).

Thomas, Charles, Jaime Marquez, and Sean Fahle, 2008, "Measuring U.S. International Relative Prices: A WARP View of The World,” International Finance Discussion Paper, Federal Reserve Board.

Tille, Cédric, 2005, "Financial Integration and the Wealth Effect of Exchange Rate Fluctuations,” Federal Reserve Bank of New York Staff Report No. 226. 